Svein Østerud Professor emeritus

\title{
Hva skjer når en nettspiller setter seg selv i scene i mediene? - Om identitetsdannelse i nettverkssamfunnet. ${ }^{1}$
}

\section{Sammendrag}

Siden midten av 1990-årene har mediene spilt en viktig rolle i de unges selvfremstilling og identitetsdannelse. Den kulturelle frisettingen mot slutten av det forrige århundre har ført til at de unge frimodig står frem og forteller historien om seg selv og sitt liv på Facebook og Twitter. Dette er en form for identitetsutprøving som er fundamentalt tvetydig. For de fleste ungdommer representerer dette en konstruktiv erfaring som gjør dem til trygge kommunikative aktører, for andre kan det bli en anledning til ytterligere forskansning i en narsissistisk karakter.

Erkjennelsen av at mediene har en slik tvetydig funksjon er utgangspunktet for denne analysen av NRKs talkshow Skavlan, den 6. november 2009. Dette er et programsjanger som forsøker å skape balanse mellom kritisk samfunnsdebatt og underholdning ved å invitere kjente personer fra samfunnslivet og underholdningsbransjen til felles samtale. I denne sendingen hadde Fredrik Skavlan invitert den bedrageridømte nettspilleren Bjarte Baasland som fikk anledning til å fortelle sin historie - en historie som for øvrig allerede var kjent fra en biografi forfatteren Håvard Rem ga ut samme høst. Hvilket inntrykk seerne får av Baaslands selvfremstilling, beror ikke bare på hans egne ord og kroppsspråk, men også på samtalepartnernes reaksjoner samt programlederens organisering av samtalen. Artikkelen tar for seg denne felles "tekstlige" iscenesettelsen og trekker veksler på blant annet sosiologisk, medievitenskapelig og psykoanalytisk teori.

\section{Gjest i TV-studio}

Den 6. november 2009 var den bedrageridømte biskopsønnen Bjarte Baasland gjest i Fredrik Skavlans talkshow Skavlan. Denne gjesten gjorde ingen vanlig entré, men ble i stedet introdusert gjennom et par, tre innslag fra tidligere nyhetssendinger i TV der han ble etterlyst internasjonalt etter å ha lånt 55 millioner kroner fra sine foreldre og deres venner, og spilt bort pengene på nettspill. Og da Skavlan inviterte publikum og seere til møte med en "notorisk gambler", satt Baasland allerede på sin plass i studio. TV-seerne fikk møte en person som satt tungt tilbakelent i

\footnotetext{
${ }^{1}$ Det er mange som har lest tidligere versjoner av denne artikkelen: Sigmund Karterud, Knut Lundby, Lars Løvlie, Ture Schwebs, Håkon Skard, Jon Magne Vestøl og Erik Østerud. Jeg skylder dem alle stor takk for verdifulle kommentarer og kritikk.
} 
stolen og snakket i velformulerte setninger, men med et unnvikende blikk, et nærmest ubevegelig ansiktsuttrykk og en monoton stemme. Intervjuet med gambleren var imøtesett med stor interesse, og det er i etterhånd blitt kjent at seeroppslutningen om programmet var rekordstor: 1, 2 millioner nordmenn og 1,7 millioner svensker så Skavlan den kvelden.

Det som vakte min interesse og fikk meg til å følge talkshowet, var fra først av det forhold at en person som hadde gamblet bort så store beløp gjennom spill på nettet og blitt straffedømt for det, fikk slippe til i et slikt program. Etter hvert ble jeg også opptatt av den rollen han fikk anledning til å spille der. Det er med andre ord ikke Baaslands personlighet jeg ønsker å rette søkelyset mot her, men den personen han gestalter i mediene, som også innbefatter en biografi om han, skrevet av forfatteren Håvard Rem. Biografien er basert på samtaler med Bjarte Baasland; omslagsteksten fastslår simpelthen at det dreier seg om en selvutlevering: "Nådeløst ærlig forteller han nå hele sin historie for første gang. Først og fremst utleverer han seg selv og sitt svik, men leseren får også innsikt i en verden av bedrageri og fortielse, avhengighet og bindinger, svik og skam.” Baasland er etter min mening interessant som mediegestalt fordi hans opptreden på den offentlige arena avspeiler generelle kulturelle tendenser i en tidsepoke hvor fjernsyn og presse, IT og Internett i økende grad konvergerer, og skaper nye vilkår for menneskers selvfremstilling og identitetsdannelse. En analyse av Baaslands iscenesettelse av seg selv på TV og i biografien kan naturligvis ikke styre unna alt det han blottlegger av private opplevelser og erfaringer. Det som kjennetegner selvets iscenesettelse i dagens postmoderne samfunn, er jo nettopp at grensene utvides for hva man stiller til skue for publikum. ${ }^{2}$

Det vi seere blir vitne til under den 15 minutter lange samtalen med Skavlan, der også noen av de andre gjestene i showet får slippe til med spørsmål og replikker, kan oppsummeres i følgende tre punkter:

1. Baasland redegjør for foranledningen til at han ble engasjert i pengespill og forsøker å beskrive spillegalskapen, slik han har opplevd den.

2. Han gir uttrykk for sterk anger og knytter angeren til den situasjonen han har satt sin nærmeste familie og deres venner i.

3. Han kommer med en programerklæring om å viderebringe sine egne erfaringer med spillegalskap og på den måten bidra til å forhindre at andre havner i samme uføre.

Disse temaene vil i tur og orden bli drøftet her innenfor rammen av generelle teorier om forholdet mellom individ og samfunn. Det er teorier som handler om identitetsdannelse i vårt høyteknologiske, postmoderne samfunn, teorier om stedets psykologi, om narsissistisk ambivalens og om følelsen av skam.

\section{Når mediene blir sosiale ...}

I 1950 publiserte sosiologen David Riesman studien The Lonely Crowd, en studie som skulle vise seg å få stor betydning for oppfatningen av identitetsdannelsen i den amerikanske befolkningen. I

\footnotetext{
${ }^{2}$ Metodisk kan det synes problematisk å pendle mellom den iscenesatte personen vi møter i Skavlans talkshow, og den biograferte personen vi leser om i Håvard Rems biografi, men biografien bygger i all hovedsak på samtaler og kan derfor betraktes som en utvidet selvfremstilling. Analysen opererer på dette tekstlige nivået og har ingen ambisjoner om å gå psykoterapien i næringen.
} 
denne studien med undertittelen A study of the changing American character introduserer forfatteren et skille mellom en indrestyrt ("inner directed") og en andrestyrt ("other directed") karakter, og assosierer dette skillet med den dramatiske endringsprosessen som han mener å kunne registrere i det amerikanske samfunnet. Den indrestyrte karakteren som dominerte det amerikanske samfunnet i det 19. århundre, er i ferd med å bli erstattet av en helt annerledes sosialkarakter, hevder han, nemlig den andrestyrte.

Begrepet indrestyrt karakter er forankret i teoriene til psykoanalytikerne Erik H. Erikson og Erich Fromm, og betegner en person som handler ut fra en slags indre psykisk tvang. Her støtter Riesman seg eksplisitt til Fromms uttalelse om at i et velfungerende samfunn utvikler medlemmene en sosialkarakter som får dem til å ønske å handle slik de må handle som medlemmer av dette samfunnet. For å oppnå dette må oppdragelsen ta sikte på effektivt å overføre foreldregenerasjonens normer og verdier til den oppvoksende slekt. Denne sosialkarakteren oppstod etter Riesmans mening under fremveksten av industrisamfunnet. Her er Riesman på linje med Max Weber som lanserte begrepet den protestantiske etikk for å betegne den asketiske pliktfølelsen som kjennetegnet menneskene under industrialismen. I forlengelsen av Webers resonnement beskriver han den indrestyrte karakteren som orientert mot utrettelig arbeid og streng selvkontroll.

Denne indre disiplineringen mistet imidlertid grepet på menneskene etter hvert som industrisamfunnet ble avløst av vare- og tjenestesamfunnet. I USA ga endringen seg utslag $\mathrm{i}$ at befolkningen begynte å opptre og oppfatte seg som konsumenter. For å betegne den sosialkarakteren som på denne måten lar ytre faktorer få avgjørende innflytelse på sine handlingsvalg, innfører Riesman begrepet den andrestyrte karakteren. I et samfunn som kunne tilby det som trengtes av varer og tjenester, var individene etter hvert omgitt ikke bare av en overflod av forbruksvarer, men også en flom av ord og bilder fra de nye massemediene. De var henvist til å oppleve virkeligheten gjennom massemedienes atomiserte og personfokuserte fremstillinger av den, og de formet sitt selvbilde under påvirkning av massemedier som film, radio og TV. ${ }^{3}$

Endringene i de unges oppdragelse og sosialiseringsvilkår gjorde seg etter hvert også gjeldende i de vest-europeiske velferdsstatene, inklusive Norge. Etter at Internett begynte å bli utbredt i allmennheten på midten av 1990-tallet samtidig som datamaskiner, mobiltelefoner, radio og fjernsyn ble integrerte medieteknologier, har mediene fått en stadig større plass i folks hverdagsliv (Lundby, 2009). Dels blir vanlige menneskers gjøren og laten stadig oftere gjort til tema i virkelighetsdrama-serier i norsk TV som Big Brother, Farmen, Robinsonekspedisjonen og 71 grader nord, dels bruker mange av oss - særlig blant barn og unge - mer og mer tid på å kommunisere via sosiale nettsteder som Facebook, Twitter, MySpace og YouTube. Hva enten det gjelder barn og unges deltakelse i TV-program eller i kommunikasjon på nettet, må lengselen etter å oppleve noe nytt og spennende, lengselen etter å bli underholdt, sannsynligvis regnes blant de viktigste motivasjonsfaktorene. Men samtidig er både TV-mediet og Internett i ferd med å bli viktige arenaer for selvfremstilling. Når de unge står frem og spiller seg selv i en TV-serie eller

\footnotetext{
${ }^{3}$ Dette temaet er nærmere redegjort for i Svein Østerud og Hans Christian Arnseth: "Læring, sosialisering og identitetsutvikling i nettverkssamfunnet”, i: S. Østerud og E. G. Skogseth (red.): Å være på nett, 2008, s. 39-59.
} 
forteller historien om seg selv og sitt liv på Facebook, prøver de ut sin identitet ved å komme med utspill for å uteske de andres reaksjoner (Lüders m.fl., 2007). ${ }^{4}$

Identitetsutprøving av dette slaget er fundamentalt tvetydig. Den kan være konstruktiv i den forstand at den gir den enkelte ungdom mulighet til å gi form til sine tanker og følelser i blogger og wikier, den gir han en stemme i klassen eller gruppen og gjør han til en trygg aktør i ethvert kommunikasjonsfellesskap. Slik kan den legge grunnlaget for et godt læringsklima i skoleklassen og for aktørens senere deltakelse i demokratiske beslutningsprosesser (Østerud m.fl., 2006). Men identitetsutprøvingen kan også være introvert og regredierende: I slike tilfeller fokuserer den kommuniserende ungdommen på å oppnå bekreftelse fra de andre på sin egen storhetsfølelse. I stedet for å bidra til videre utvikling og vekst hos den unge kan kommunikasjonen når den tar en slik vending, komme til å fastholde han på et tidlig utviklingsstadium.

At mediene kan ha en positiv funksjon i unges identitetsbygging, er etter hvert blitt dokumentert gjennom flere studier (Livingstone, 2002; Lüders m. fl. 2007; Drotner, 1995; Drotner og Livingstone, 2008). Men forskningen har hittil vært lite opptatt av de mer betenkelige funksjonene mediene kan få når de unge benytter dem til å iscenesette seg selv. Tilfellet Baasland synes å være egnet til å kaste lys over noen av dem.

\section{Spillets virtuelle verden}

I TV-intervjuet forteller Bjarte Baasland at han hadde sin første befatning med spill på utenlandsturer i forbindelse med arbeid. Han var ute etter underholdning; med det for øye oppsøkte han kasinoer i utlandet, der han spilte for småbeløp. Når han satt ved et kasinobord, følte han at han klarte å glemme alt rundt seg, han greide å "glemme hverdagen som var hjemme". I slike kasinoer kunne han "slappe helt av, som var befriende”. Da han fikk Internett hjemme i 1998, erfarte han at det var mulig å bringe spillverdenen inn i sin egen stue. Han kunne sitte alene foran en PC og oppnå den samme "avkobling fra hverdagen der og da”.

I 2005 da Baasland begynte å tro at den foretaksvirksomheten han hadde startet, ville bli slått konkurs, fikk han problemer med å takle sin vanskelige situasjon. Som han selv uttrykker det, ønsket han da å "få et pustehull og komme meg litt bort, som de fleste kan oppleve når det blir for mye”. Derfor reiste han til utlandet - først til Tyskland og deretter til Praha. Men det som var planlagt som et to ukers feieopphold, ble til tre år i utlendighet. Før han reiste, fortalte han sin mor at han hadde fått en del problemer og ba henne om hjelp til å håndtere situasjonen. Moren valgte å gi han pengelån for å hjelpe han med yrkeskarrieren. I starten var det hennes egne midler hun øste av, men etter hvert ble summene så høye at hun måtte be sine venner om hjelp.

Den første store gevinsten vant han kort tid etter at han hadde tatt fatt på sitt utenlandsopphold. Det dreide seg om oddstipping, og han satte sammen ti kamper med en totalodds på 50 ganger innsatsen. Han satset 25000 kroner og vant 1,1 millioner. På Skavlans spørsmål om hvordan han feiret denne gevinsten, svarer han at han "aldri har vært noe særlig bymenneske”, at

\footnotetext{
${ }^{4}$ Mens livsløpet i det tradisjonelle samfunnet var tradisjonsavhengig og i stor utstrekning definert på forhånd, er selvutvikling i dag et refleksivt prosjekt. Sosiologen Anthony Giddens beskriver det senmoderne menneskets identitetsfølelse slik (1991, s. 54): "A person with a reasonably stable sense of self-identity has a feeling of biographical continuity which she is able to grasp reflexively and, to a greater or lesser degree, communicate to other people."
} 
han var alene i utlandet da han vant premien, og at han ikke levde "noe særskilt luksusliv" der. Så det ble til at han tok trikken til sentrum og kjøpte en milkshake på McDonalds.

I intervjuet blir Baasland oppfordret til å beskrive sin hverdag i utlandet; han blir spurt om han satt på hotellet hele dagen. Dette bekrefter han og tilføyer: "Det som er så skummelt med internettselskapene, er at det blir en verden som foregår mellom spilleren og maskinen som du ser på”. Han forklarer at når du går på kasino i utlandet, har det for det første en fysisk side ved at du må gå dit, og det har også en menneskelig side ved at det er mennesker rundt deg som passer på: "Du tar hånd om dine verdier på en annen måte når du er i møte med andre mennesker, som er der”. Selv satt han på hotellet med PC'en og noen tall som han "ikke skjønte hva var”, de var "mer tall enn penger". Skavlan innvender at han måtte forstå at det dreide seg om store summer, og får til svar: "Man får ikke det samme forholdet til penger når man driver med nettspill. Som en spilleavhengig tenker du ikke at pengene er tapt. De kan vinnes tilbake. Helt frem til det siste lånet trodde jeg at alt skulle betales tilbake.”

\section{Mellom en reell og en virtuell verden}

Med anskaffelsen av Internett hjemme fikk Bjarte Baasland adgang til en virtuell verden, som Internett gir opphav til. Han kontrasterer selv den spillverdenen på nettet som han nå kunne tre inn i mens han satt i sin egen stue, med den fysiske verden som han tidligere måtte oppsøke utenfor landets grenser (kasinoer har hittil vært forbudt i Norge) for å oppnå den avkobling og underholdning han følte behov for. Her illustrerer Baasland den omveltningen som den canadiske medieteoretikeren Marshall McLuhan (1964) beskrev ved hjelp av metaforen den globale landsby ("the global village”): at jordkloden er blitt sammentrengt til en landsby takket være elektronisk teknologi og den momentane informasjonsstrømmen mellom alle stedene på kloden. McLuhan ser mediene som forlengelser av menneskets sanseapparat, og det er nettopp hva de blir for Baasland når han kan sitte i sin stue og kommunisere med hele verden, uten å behøve å forflytte seg i rommet.

I sammenligningen mellom den fysiske verden han beveget seg i da han oppsøkte spillekasinoene i utlandet, og den virtuelle verden han får tilgang til på Internett, peker Baasland på et par markante forskjeller. I det fysiske kasinomiljøet finnes det noen normer samt noen mennesker som ser til at disse normene blir overholdt, men i den virtuelle verden på Internett finnes det ingen slike sperrer. Heller ikke verdiene er de samme: I vår fysiske virkelighet utgjør penger en relasjon mellom mennesker - enten det dreier seg om lån eller gjeld, arv eller kjøp og salg, men i den virtuelle spillverdenen representerer penger bare abstrakte tall, størrelser som er frikoblet fra menneskelig verdisetting. Men fremfor alt representerer den virtuelle verdenen en utopi, en verden hvor tapte penger kan vinnes tilbake, hvor drømmer og fantasier kan bli virkelighet.

Det som i Bjarte Baaslands tilfelle startet som en trang til adspredelse og underholdning, utviklet seg etter hvert til et spill med rehabilitering som den ettertraktede gevinsten. Da han dro utenlands og bega seg nettspillet i vold, var det angivelig fordi han hadde problemer med yrkeskarrieren. Han var som nevnt truet av konkurs og måtte be sin mor om økonomisk hjelp, da han reiste vekk fra problemene hjemme. 
Hva problemene bestod i, forteller Baasland mer om i den biografien Rem utga på Schibsted forlag kort tid før TV-intervjuet, under tittelen Peter Pilný - Historien om Bjarte Baasland. I samtaler med sin biograf har Baasland redegjort for en serie nederlag som han ble påført i sitt yrkesliv i årene 1999-2005. Vi får vite at han først forsøkte seg som lærervikar i grunnskolen i Oslo for deretter å skrive og utgi Ressurshefte for vikarer i grunnskolen, et hefte som var ment som en slags førstehjelp for lærervikarer (Baasland og Mosvold, 1999). Heftet ble omtalt i bladet Skolefokus (nr. 14, 1999), med både forside og lederartikkel, samt fire helsider og et foto av Bjarte Baasland under overskriften "Pirater på vikarmarkedet”. Anmeldelsen var et fullstendig slakt både av produktet, forfatteren og markedsføringen. Baasland klaget Skolefokus inn for Pressens faglige utvalg, men fikk ikke medhold til tross for at også hans far, biskop Ernst Baasland, engasjerte seg i saken. Det hele endte med at Bjarte Baasland ble stående igjen med tapet av aksjekapitalen på 50000 kr og en gjeld på 80000 kr.

En langt mer alvorlig kritikk ble rettet mot Baasland fem år senere da han ble avskjediget fra stillingen som sekretariatleder i organisasjonen First Tuesday, et nettverk for forskere, entreprenører, politikere, investorer og næringslivsaktører. Han ble anklaget for å ha tappet selskapets bankkonto for 1,2 millioner kroner, og fikk ifølge en av aksjonærene valget mellom å gjøre opp for seg eller bli anmeldt til politiet. For å dekke underskuddet ba han sin mor om et lån, som han fikk uten å måtte gjøre rede for hva lånet skulle brukes til. Etter det satset han som frilanser på å utgi en valgavis før stortingsvalget 2005, men også dette initiativet endte i et økonomisk uføre. Han spilte bort en stor del av annonseinntektene og ble til slutt slått konkurs.

Det finnes en undertekst i Baaslands beretning, både i de fragmentene vi får del i gjennom TV-intervjuet og i den mer fullstendige versjonen vi kan lese i biografien, en tekst om en mors kjærlighet til sin sønn og hennes ønske om at han skal lykkes med yrkeskarrieren, og sønnens håp om å bli forsonet med familien og igjen få feire jul i barndomshjemmet. Det er ikke bare håpet om å vinne tilbake de tapte lånepengene som driver han stadig lengre inn i spillets virtuelle verden. Han synes også å være drevet av et begjær etter å lykkes, etter å utføre en bedrift som kan skaffe han aksept og anerkjennelse hos familien. Drømmen om den store pengegevinsten er vevet sammen med en drøm om å lykkes på det personlige plan, en drøm om å bli sett og anerkjent som person. En forsmak på dette opplevde han da han ved et par anledninger vant store gevinster i nettspill og ble hyllet som en helt i norske medier - de samme mediene som senere skulle fremstille han som en forbryter.

\section{Den fysiske verden må vike}

Den globale landsbyen - McLuhans metafor for den samfunnsformen han spår at de nye mediene vil bringe med seg - har ofte vært tema for drøfting og nyfortolkning. Ifølge McLuhan vil de elektroniske mediene kunne gjenskape tidligere tiders landsbyfellesskap, som var tette samfunn der folk kjente hverandre og hadde nær kontakt. ${ }^{5}$ De nye mediene vil gjøre det mulig for oss å

\footnotetext{
5 Det er et nært slektskap mellom den tyske sosiologen F. Tönnies’ begrep Gemeinschaft og McLuhans globale landsby. Tönnies (1926) beskriver Gemeinschaft som det enkle lokale og solidariske samfunnet som er i ferd med å gå til grunne og bli avløst av den moderne komplekse samfunnsformasjonen, Gesellschaft, preget av løse upersonlige bånd eller kontraktsforhold mellom mennesker, slike vi finner på markeder.
} 
opprettholde nær kontakt med folk i andre deler av verden, slik at hele kloden ideelt sett vil kunne utvikle seg til et slikt fellesskap.

En videreføring og nyansering av denne teorien finner vi i R. Robertsons artikkel “Globalization: time-space and homogeneity-heterogeneity” (1995), der forfatteren peker på at globaliseringsprosessen løper parallelt med en annen prosess, nemlig lokalisering. For å markere at de to prosessene er vevet inn i hverandre, og at de påvirker hverandre gjensidig, innfører han det sammensatte begrepet glokalisering ("glocalization"). Det er velkjent at den standardiseringen eller formlikheten som globaliseringen fører med seg, ofte er ledsaget av økte forskjeller i innhold. Det er først når våre lokale særtrekk blir satt under press, at vi begynner å fremheve dem.

Vår identitetsutvikling er kjennetegnet ved et lignende paradoks. I dagens samfunn er det mange som forblir stedbundne, selv etter at de har begynt å dele sin tid mellom flere hjemsteder. De blir det sosiologen Ulrich Beck har kalt "stedspolygame”, dvs. at de har bosted i to forskjellige land eller tilmed kontinenter (Beck, 2000). Men for de fleste av oss utgjør mediene den viktigste kanalen til den verden som befinner seg utenfor hjemstedet. Sosiologen Zygmut Bauman har omtalt fjernsynet som "våre kunstige øyne som setter oss i stand til å se det som våre øyne aldri ville kunne se” (Bauman 2001), og når vi dertil via Internett kan foreta virtuelle reiser hvor som helst i verden, vil vi kunne leve i en lokal og en global verden på samme tid. Det finnes mange eksempler på at mennesker oppnår både å få styrket sin lokale tilhørighet gjennom kommunikasjon på nettet og å utvikle solidaritetsrelasjoner til grupper av mennesker i andre regioner og land, når disse blir innlemmet i kommunikasjonsnettverket (Rheingold, 1993). Et illustrerende eksempel her hjemme er det IKT-baserte politiske nettverket Oslo Byforum, som fra starten av i 2001 tok mål av seg til å mobilisere flest mulig borgere til aktiv deltakelse i bydelenes politiske beslutningsprosesser, samtidig med at det via Internett satset på å opprettholde samarbeidsrelasjoner med tilsvarende fora i andre byer både innenlands og utenlands (Andersen, 2008; Andersen m.fl., 2008).

Mon ikke slike fora fungerer som workshops for fremveksten av det enkelte forskere har kalt en kosmopolitisk identitet og definert som “evnen til å leve lokalt og globalt samtidig” (Kemp, 2005; Rantanen, 2005; Vettenranta, 2010)? Dagens norske læreplaner inneholder en dannelsesmålsetting som peker nettopp i denne retningen: Skolen skal forberede de unge til deltakelse i demokratiske beslutningsprosesser. Men det å være politisk deltaker i lokale fellesskap som blir mer og mer flerkulturelle, vil i økende grad kreve bevissthet om at vi lever i en globalisert verden (Kunnskapsløftet). Mange av dem som vokser opp i dagens samfunn, kan sies å inneha en dobbel identitet. Det er nærliggende å assosiere et slikt begrep med innvandring til Norge og tenke på dem som har en annen etnisk bakgrunn, og kommer for å bli norske statsborgere. Men også etniske nordmenn kan utvikle en form for dobbelt identitet ved å pendle mellom det lokalmiljøet de tilhører, og den virtuelle verden de får tilgang til gjennom Internett. For dem utgjør den virtuelle verden både et supplement til og en utvidelse av den fysiske verden de lever i. De bruker Internett både til å forsterke kommunikasjonen i sin nære omgangskrets og til å skaffe seg informasjon og kunnskap om verden utenfor.

For andre utgjør derimot den virtuelle verden både en motpol til og en erstatning for en fysisk verden de ikke finner seg til rette i. Bjarte Baasland synes å tilhøre denne siste kategorien 
mennesker. Som allerede nevnt reiste han utenlands for å komme bort fra en virkelighet han opplevde som besværlig, og da han vendte tilbake tre år senere, hadde det sammenheng med at han var etterlyst gjennom Interpol. I de tre årene han tilbrakte i utlandet, satte han den fysiske virkeligheten så å si i parentes. De stedene han oppholdt seg i disse årene, Berlin og Praha, fikk ingen annen betydning for han enn som kulisser for aktivitetene på nettet. Vi tillegger gjerne steder som vi knytter oss til, en tredobbelt symbolfunksjon: Vi assosierer dem med relasjoner mellom de menneskene som oppholder seg der, med deres identitet og deres felles historie. Den engelske samfunnsgeografen Mike Crang hevder at vi definerer oss selv gjennom vår opplevelse av stedet hvor vi slår oss ned. Han setter stedet ("place") opp mot rommet ("space"), som han oppfatter som en abstrakt og innholdstom størrelse (Crang, 1998: 102):

Places provide an anchor of shared experiences between people and continuity over time. Spaces become places as they become 'time-thickened'. They have a past and a future that bind people together round them. The lived connection binds people and places together. It enables people to define themselves and to share experiences with others and form themselves into communities.

Crangs resonnement er en videreføring av medieforskeren Joshua Meyrowitzs innflytelsesrike studie fra 1985, No Sense of Place, der forfatteren hevder at de elektroniske mediene er i ferd med å endre den geografiske situasjonen for vår sosiale atferd. Når vi kommuniserer via telefon, radio, fjernsyn eller datamaskin, er vi i fysisk forstand ikke lenger bestemt av hvor vi er, og hvem vi er som sosiale individer, hevder Meyrowitz. Vår identitet er da uten noen form for stedsforankring. For første gang i moderne historie lever vi uten tilknytning til et bestemt sted; takket være mediene og kommunikasjonsteknologien beveger vi oss i en global verden. Denne utviklingen diagnostiserer han som en identitetskrise.

Bjarte Baaslands tre år i utlendighet er et illustrerende eksempel på den tidstendensen som Meyrowitz og Crang beskriver. Hans uttalelse i TV-intervjuet om at han aldri har vært noe særlig bymenneske, må oppfattes som et understatement, og beskrivelsen av hvordan han i ensomhet feiret milliongevinsten i Praha med en tur med trikken til McDonalds, er en selvironisk avsløring av et liv som helt mangler fysisk og sosial forankring. Til biografen Håvard Rem har han fortalt at det kunne gå to, tre uker mellom hver gang han beveget seg utenfor det hotellet han bodde på. Både i Praha og Berlin levde han et uforutsigbart og oppstykket liv, med sikkerhet for bare to hotelldøgn om gangen, inntil han endte med total utrygghet som uteligger i Prahas parker. Mens han bodde utenlands, la han seg til vanen med å reise på dagsturer hjem til Norge, enten med Kiel-ferga eller med fly. Ved ankomst i Norge foretok han en handlerunde i sentrum før han tok flytoget til Gardermoen, hevet kontanter i Nordeabanken og spiste en enkel lunsj i en kafeteria. Så satte han seg på flyet for å vende tilbake til Praha eller Berlin. Sine erfaringer høstet han i ensomhet og på slike anonyme steder som den franske sosialantropologen Marc Augé (1995) har kalt ikke-steder ("non-places”): flyplasser, shoppingsentre og fast food restauranter.

I vårt supermoderne samfunn tilbringer et økende antall mennesker mer og mer tid i dette rommet av ikke-steder, der de blir behandlet som kunder, passasjerer, brukere og publikum, hevder Augé. Dette er ikke et rom som gir den enkelte mulighet til utvikling av egen identitet, for interaksjonen med de andre er definert gjennom billetter, pass og passersedler, visakort og kontanter. Enten han var ute på en av sine dagsturer, eller han oppholdt seg på et luksushotell i Praha eller Berlin, befant Baasland seg i permanent transitt under hele utenlandsoppholdet. Ikke nok med at den fysiske verden fungerte som en kulisse for aktivitetene på nettet, den var til 
overmål et ikke-sted eller snarere en serie ikke-steder som Baasland rutinemessig pendlet mellom. Han hadde med andre ord ikke til rådighet noen arena for sosial læring. I stedet forsøkte han - som vi snart skal se - å omgi seg med objekter som kunne være egnet til å gi han en etterlengtet anerkjennelse og selvbekreftelse.

\section{Narsissistisk ambivalens}

På 1970-tallet fikk David Riesmans teori om indre- vs. andrestyrt identitet en oppfølger i de såkalte narsissismeteoriene, som opprinnelig ble utviklet av psykoanalytikerne Heinz Kohut (1971) og Otto F. Kernberg (1975) gjennom kritiske drøftinger av Sigmund Freuds klassiske essay om narsissistisk personlighetsforstyrrelse. Deres innsikter ble i sin tur tatt opp av den amerikanske kulturanalytikeren Christopher Lasch, som i studien The Culture of Narcissism med undertittelen American Life in An Age of Diminishing Expectations (1978) nedfelte dem i en teori om en tidstypisk narsissistisk sosialkarakter. Til forskjell fra de nevrotiske karakterene med veldefinerte symptomer som Freud behandlet, har dagens pasienter mer diffuse psykiske lidelser, hevdet Lasch, de er utilfredse med livet, føler tomhet og depresjon og opplever voldsomme svingninger i sin selvfølelse. En høynet selvfølelse kan de bare oppnå ved å knytte seg til sterke personer som de beundrer, personer som de ønsker skal akseptere og støtte dem.

Lasch betraktet denne patologien som en intensivert variant av normaltilstanden i det amerikanske samfunnet. Langt på vei så han narsissismen som en metafor for menneskenes vilkår i det moderne kapitalistiske USA. Opprinnelig er vi alle narsissister: Som nyfødte er vi ute av stand til å forstå at mor, som tilfredsstiller våre behov etter hvert som de oppstår, har en selvstendig eksistens utenfor oss selv. Slik forveksler det nyfødte barn sin totale morsavhengighet med egen omnipotens. Sekundær narsissisme oppstår når barnet vokser opp og opplever atskillelsen fra moren som så traumatisk at det prøver å gjenskape den opprinnelige kjærlighetsrelasjonen til moren i egne fantasier og drømmer. En slik karakter blir sittende fast i det narsissistiske stadium, henvist til stadig å svinge mellom aggresjon mot personer som berøver han eller henne bekreftelse og empati, og grandiose forestillinger om seg selv, basert på positiv respons fra omgivelsene. En narsissist vil alltid være på jakt etter objekter som kan speile hans eller hennes grandiose selv ved å gi vedkommende følelsen av å bli sett, gjenkjent, akseptert, verdsatt, anerkjent, forstått, beundret og lignende.

Den tyske sosialpedagogen Thomas Ziehe (1975, 1983) modifiserte teorien ved å poengtere de utviklingsmulighetene narsissismen gir det enkelte individ. I og med at dagens ungdom vokser opp "frisatt” fra foreldrekulturens tyngende normer og omgangsformer, har de fått en økt mulighetshorisont. At det enkelte individ er overlatt til seg selv og må utforme sin egen identitet, er ikke nødvendigvis en negativ særegenhet ved det moderne mennesket. Den kulturelle frisettelsen innebærer en utvidelse av hva individet kan forvente, lengte etter og drømme om. Den økte refleksiviteten som følger med de nye mediene, har gitt individet helt andre muligheter enn tidligere til å se seg selv "utenfra”. Den enkelte ungdom kan prøve ut sin identitet overfor de andre, overvåke deres reaksjoner og så foreta justeringer eller endringer av identiteten. For noen kan narsissismen således bli en mulighet til å skape seg selv (Drotner, 1995; Østerud, 1994), for andre kan den føre til identitetshavari om de ikke klarer å takle den narsissistiske ambivalensen. 
Narsissisme handler egentlig om individets iscenesettelse av seg selv. Liksom ynglingen Narsissos i gresk mytologi søkte sitt eget speilbilde, er en narsissist opptatt av å se seg selv speilet i omgivelsene. Men i motsetning til Narsissos som druknet i sitt eget speilbilde, kan speilingen bli et incitament til selvinnsikt og selvutvikling. Det er dette som i beste fall skjer når de unge legger ut på nettet selvbiografiske data i form av bilder, tekster og tale, eller når de får muligheten til å iaktta seg selv som agerende på film eller video. Men ungdommelig selvspeiling er samtidig ytterst ambivalent; for enkelte kan den bety en rastløs pendling mellom omnipotenspretensjoner og depressiv tilbaketrekking.

Det er slik ambivalensen ytrer seg hos Bjarte Baasland. Til biografen har han fortalt om vekslingen mellom øyeblikk hvor han enten vant store gevinster eller gikk i forventningsrus og med klokkertro på at lykken snart ville snu og gå hans vei, og øyeblikk hvor han følte seg presset av sine kreditorer og sank ned i dyp depresjon. Svingningene i sinnsstemning mellom følelsen av omnipotens og følelsen av nedstemthet er selve hovedtemaet i biografien om Bjarte Baasland.

Hos en narsissist manifesterer dette seg gjerne som en periodisk veksling mellom ønsket om å være synlig i offentligheten og ønsket om å være usynlig. En anekdote som Baasland har gjenfortalt til sin biograf, illustrerer at han har gjennomlevd en lignende ambivalens. Ikke uten selvironi har han fortalt at han i 1996 stiftet sin egen fotballklubb, en klubb som skulle være for alle og betegnende nok fikk navnet Røkla IL. ${ }^{6}$ På spørsmål fra Rem om på hvilken plass i laget han selv spilte, svarer han (Rem, 2009: 56):

Indreløper. Eller høyre ving. Jeg var ikke god nok til å vcere spiss, og jeg var ikke god nok til å spille på midtbanen eller i midtforsvaret. Jeg ble satt et sted hvor jeg var mest mulig usynlig.

Men samtidig tegner han et diametralt motsatt bilde av sin egen rolle i laget ved å gjengi en hendelse som etter hvert er blitt legendarisk i klubben (Rem, 2009: 56):

Men jeg hadde tidenes mål i Røkla. Jeg fikk ballen på midtbanen, driblet av tre stykker og så skjøt jeg fra tredve meter rett i krysset. Når de snakker om det nå, er det blitt 40-50 meter.

For Baasland må denne episoden ha representert et anerkjennelsens øyeblikk, et øyeblikk hvor lagkameratenes blikk var rettet mot han og hvor de med gester og kroppsspråk hyllet hans prestasjon. ${ }^{7}$ Det er et øyeblikk i livet hvor han har suksess, og hvor han blir synlig i kraft av å lykkes.

La oss vende tilbake til det fenomenet som denne anekdoten illustrerer. Som nevnt definerer Lasch sekundærnarsissisme som en persons vedvarende anstrengelse for å gjenskape den opprinnelige kjærlighetsrelasjonen til moren. Mon ikke dette er grunntemaet i Bjarte Baaslands liv? I TV-intervjuet etablerer Bjarte Baasland selv en sammenheng mellom egen suksess og morens kjærlighet til sin sønn: "Jeg ser det sånn at hun ville hjelpe sin sønn av ren morskjærlighet, hun ville strekke seg langt for at sønnen skulle lykkes.” Hans vedvarende forsøk

\footnotetext{
${ }^{6}$ Med det foregrep han det sosiale fenomenet som et tiår senere ble kjent under navnet Tufte IL, og ble viet stor oppmerksomhet i TV.

${ }^{7}$ I romanen Fodboldenglen (1979) beskriver den danske forfatteren Hans-Jørgen Nielsen en narsissistisk ungdomsgenerasjon som vokste opp i København i 1960-årene i et miljø hvor fotballen stod i sentrum. Tittelen henspiller på ledemotivet i romanen, bildet av en fotballspiller, som kan minne om en engel der han henger, hvitkledd, alene høyt i luften, idet han setter hodet til ballen og styrer den i mål. Det er dette berusende øyeblikket som blir målestokken for de unge når de møtes ti år senere og gjør opp status for sine karrierer.
} 
på å vende nettspillet til egen fordel later i siste instans til å være motivert av ønsket om å gjøre seg verdig til morens kjærlighet. Det er betegnende at han bærer på et fremtidsønske om familieforsoning og om igjen å få feire jul i barndomshjemmet. Dette ønsket har Håvard Rem latt stå som sluttord i biografien (Rem, 2009:454f.):

Midt i all fortvilelse og alle problemer har jeg opplevd at familiebånd ikke er skåret over. Blant annet har jeg jo fått mye støtte fra mine brødre og en tante. Jeg vet at heller ikke mine foreldre har kuttet båndene til sin eldste sønn. Mitt største ønske er at min mor beholder sin helse, for jeg tror at vi med tiden kan komme oss gjennom også dette. Jeg ville forstått om jeg i fremtiden ikke ble invitert hjem til jul, men jeg tror at julens budskap vil bringe oss sammen.

Bjarte Baaslands ønske om hjemkomst og forsoning med familien står i skarp kontrast til det livet han levde under utenlandsoppholdet. Det som begynte som en flukt fra en mulig straffeforfølgelse, utviklet seg etter hvert til en permanent bestrebelse på å være minst mulig synlig for omgivelsene. I TV-intervjuet forteller han at han var alene i utlandet; i biografien får vi vite at han gjentatte ganger reiste inkognito til Oslo, at det eneste mennesket han hadde kontakt med var moren, og det var per telefon eller SMS. På spørsmål fra biografen om hun var den eneste han hadde regelmessig kontakt med i de tre årene han oppholdt seg i utlandet, svarer han (Rem, 2009: 240):

Ja. Selv ikke andre familiemedlemmer klarte jeg å snakke med. Den eneste jeg greide å snakke med fra Norge, var min mor. Det var fordi hun visste om alle lånene. Jeg tror at også hun syntes det var godt å prate med meg, kanskje fordi hun følte på den samme skammen.

Det er en defensiv fase i en persons selvutvikling som kommer til syne gjennom denne uttalelsen. En narsissistisk karakter oppfatter verden som et speil for seg selv, og når speilet ikke kaster tilbake det bildet han ønsker å se, viker han tilbake. Narsissisten er uendelig sårbar - grenseløst høyt oppe så lenge han blir feiret som en helt, og bunnløst fortvilet når verden ikke lenger bekrefter hans idealiserte selvbilde. ${ }^{8}$ Baasland har i samtale med biografen gitt uttrykk for at han hadde behov for å "skjerme seg mot” de skadelige nyhetene han visste ville komme til å prege offentligheten, og i sitatet ovenfor vedkjenner han seg den følelsen som lurer under all usunn narsissisme, følelsen av skam.

\section{Skam og skyld}

I psykoanalysen brukes ofte begrepene skam og ære for å betegne ytterpunktene i narsissistens følelsesregister. En narsissists følelsesliv svinger mellom opplevelsen av å bli hedret og få sitt

\footnotetext{
${ }^{8}$ I sitt forsøk på å “knekke Knausgård-koden” ser Eivind Tjønneland (2010) forfatterens narsissisme som nøkkelen til forståelsen av hans dikteriske univers (s. 35): "Men hvis omgivelsene ikke fungerer som et speilbilde av subjektet, går verden mot en, og man faller sammen til et ingenting. Jeget er enten alt eller intet. Disse ytterpunktene uttrykker labiliteten til det moderne narsissistiske subjektet.” Tjønneland identifiserer også Knausgårds “private patologi” (s. 31): Dels har han en eksibisjonistisk trang til å være i sentrum, som han innrømmer i intervjuet med Tore Renberg i Samtiden, men samtidig ønsker han å ikke være synlig i det hele tatt.”
} 
grandiose selvbilde bekreftet av omgivelsene, og opplevelsen av å være berøvet de andres anerkjennende blikk og i stedet ha pådratt seg skam.

Også i sosialantropologien har skambegrepet fått en sentral plass etter at den amerikanske antropologen Ruth Benedict i The Crysanthemum and the Sword (1946) innførte skillet mellom skamkulturer og skyldkulturer. Hun hevdet at det tradisjonelle Østens kulturer som den japanske og den kinesiske er skamkulturer, mens USA har en skyldkultur. Likeledes har det katolske Vesteuropa en skamkultur i motsetning til det protestantiske som har en skyldkultur. Dette skillet setter Benedict i sammenheng med forskjeller i graden av utvikling av industrikapitalismen. Skyldfølelse fører til foretaksomhet: Den skyldbetyngede føler trang til å gjøre godt igjen det som er galt, eller til å straffe seg selv ved hardt arbeid. Skammen, derimot, lammer handlingsevnen.

Som karakteristikker av kulturer eller kulturnivåer har disse to begrepene også vært viktige hjelpemidler i vår forståelse av antikken. Det homeriske samfunn som er beskrevet i Iliaden, problematiserer skammens etos: Helten Akillevs' atferd er helt og holdent orientert mot å høste ære og unngå å pådra seg skam. Konsekvensene av heltens atferd vedrører ikke bare han selv, men hele hans slekt. I et slektssamfunn som det homeriske samfunnet var, er det slektens ære som til enhver tid står på spill. Dersom ett medlem av slekten pådrar seg skam gjennom sin atferd, påhviler det hele slekten en plikt til å gjenopprette den tapte æren - om nødvendig gjennom blodhevn (Østerud, 1976; Østerud, 1982). Vi har fortsatt å gjøre med skamkulturer; ikke minst erfarer vi det i norske rettssaler hver gang det skal felles dom i saker som dreier seg om blodhevn eller æresdrap. I vår vestlige kultur vil den som begår en slik handling, være hjemfallen til straff, men i India og Pakistan som har skamkulturer, vil handlingen være akseptert som en naturlig del av deres levesett.

I den grad vi snakker om skam innenfor rammen av vår egen hypermoderne kultur, dreier det seg om individuell skam av det slaget psykoanalysen er opptatt av. Hos oss er skammen blitt transportert fra å utgjøre en kollektiv norm til å være en individuell norm (Frønes, 2001). Mens følelsen av skyld skriver seg fra over-jeget som straffende instans, er skam assosiert med følelsen av ikke å makte å realisere jeg-idealet - hvis vi skal formulere kontrasten i freudianske termer.

Et av de viktigste bidragene til vår forståelse av fenomenet skam er amerikaneren Leon Wurmsers bok The Mask of Shame fra 1981. I kapitlet "Shame, the Veiled Companion of Narcissism” redegjør han for sine erfaringer med pasienter i terapi og trekker den konklusjon at skam er nært forbundet med kroppen vår, med følelsen av ikke å kunne kontrollere den, eller av å bli begrenset av den. Slik kan kroppen bli en kilde til ydmykelse; den kan blottstille oss som ufullkomne individer. Derfor blir det om å gjøre å skjule seg for de andre. Den som skammer seg, velger å holde avstand ettersom han er mer opptatt av hva andre mennesker vil si, tro og mene enn av egne, indre verdinormer. Den skamfulle fortier, benekter eller lyver, der den skyldbetyngede er åpen, velger å bruke ord og komme med innrømmelser. Mens ekte skyldfølelse beror på indrestyrt ansvarlighet og bærer i seg potensialet til endring og forbedring, er skam en sosialt rettet følelse som rommer lite eller intet forbedringspotensial. I den grad man overhodet kan snakke om ansvarlighet hos den skamfulle, er det en sosialt tilpasset ansvarlighet.

Med tittelen The Mask of Shame henspiller Wurmser på det gammelhøytyske ordet scama/sceme som betyr "dekke til, skjule, maskere”. Flere av hans pasienter brukte formuleringer av typen "det var som om jeg bar maske” når de i terapitimene fortalte om sine skamerfaringer. I Baasland-biografen støter vi på en beslektet metafor, "synke under jorden” (Rem 2009: 385), som kan tyde på at Baasland tenker i samme baner: Han ønsker å skjule sitt ansikt for de andre. Og på 
biografens spørsmål om han kan ha ordlagt seg slik at han har fått moren til å tro at han planla selvmord, svarer han (Rem, 2009: 386):

Ja, jeg forstår at man kan se dem [ordene] sånn. Men det er en forskjell. Jeg var aldri konkret overfor henne. Og i mine egne tanker hadde jeg aldri konkrete planer om å gjøre noe. Jeg ønsket ikke å forsvinne. Men det var jo sant det jeg sa, at man måtte flykte eller gå under jorden hvis det faktisk kom for en dag, det som var blitt gjort.

Han ønsket ikke å “forsvinne” i betydningen "begå selvmord”, bare "flykte eller gå under jorden”, og det er en bekjennelse han deler med flere av Wurmsers pasienter. ${ }^{9}$

Masken kan også ha en annen og mer offensiv funksjon. Den som ikler seg maske, kan handle, og forventes å handle, uten skam. Den maskerte kan vise seg for de andre mens han skjuler seg, og slik gjøre narr av dem eller få makt over dem. I folketroen anses maskering for å være både en form for avpersonalisering og en identifikasjon med fryktinngytende og hevngjerrige ånder. ${ }^{10}$ Hos Baasland finner vi også ansatser til en avpersonalisering. Denne prosessen skjedde ikke gjennom maskering i bokstavelig forstand, men ved at han under sitt utenlandsopphold lot seg representere i en rekke e-post meldinger av noen pågående aliaser - fiktive personer som må kunne betraktes som utspaltninger av han selv. I tur og orden skapte han personene Tor Egil Borrevik, Sandra Beck, Lars Tjern og Peter Pilný, og lot dem sende insisterende og til dels truende e-post meldinger til långiverne i Norge. ${ }^{11}$

Avpersonalisering ytrer seg også som en stivnet forsvarsholdning; Wurmser omtaler det som "selvets forstening” ("petrification”) og gir følgende definisjon: "a character defense against shameful exposure by freezing inhibition, denial, and reaction formation into 'a concrete wall' of restraint” (Wurmser 2009: 85). Mon det ikke er slik forstening eller - for å bruke Wurmsers metafor - "konkret forskansningsmur" Baasland beskriver når biografen ber han forklare hvordan han i løpet av årene i utlandet kunne spise alle de rundt tre tusen måltidene helt alene (Rem, 2009: 445)?:

Grunnen til at jeg ikke fløy på veggen i utlandet, var at jeg trengte denne flukten, trengte å vœre for meg selv og ikke forholde meg til andre, ikke måtte forklare problemene mine. Hvis det var bare meg, var jeg sikker på at jeg ikke kom borti noe jeg ikke kunne takle der og da. Derfor stengte jeg meg ganske bevisst ute, og som sagt var det jo sånn at det kunne gå et par uker før man var utendørs. [...] Jeg vet ikke om man skal kalle det en depresjon eller hva man skal kalle det, men det var i hvert fall noe psykologiske greier inne $i$ bildet. For det var sånn at man knapt lo en eneste gang i løpet av ...

I artikkelen “Tapte ansikter. Introduksjon til en skampsykologi” etablerer psykiateren Finn Skårderud, med inspirasjon fra Wurmser, en typologi over "skammens figurer” (Skårderud, 2001). I denne analysen er Skårderud særlig opptatt av ungdom som lider av spiseforstyrrelser.

\footnotetext{
${ }^{9}$ Wurmser henter også eksempler fra litterære figurer som King Lear hos Shakespeare. Flere andre psykoanalytikere har laget analyser av litterære figurer; mest kjent er trolig Freuds analyser av driftslivet til Ellida Wangel i Henrik Ibsens Fruen fra havet og den fortrengte ødipalkonflikten hos Rebekka West i Rosmersholm.

${ }^{10}$ Wurmser henviser til Hegels tolkning av sammenhengen mellom skam og maske: "While shame, to quote Hegel [...], is the wrath over one's imperfection and limitation, masking lifts one into a realm of immortal types and illuminates the transpersonal in the person, the eternal in the present, the cyclical in unidirectional history, the invisible in the visible" (Wurmser 1981: 306).

${ }^{11}$ Både de falske e-postene og svarene på dem er gjengitt i Rems biografi.
} 
Men beskrivelsen av kroppsspråket til en pasient med spiseforstyrrelser, har gyldighet for alle som bærer skam (Skårderud, 2001: 42):

Den som bærer kronisk skam, lar seg identifisere. Kroppen stivner, og mimikken flates ut. De spontane bevegelsene avbrytes. Kroppen lukker seg. Talen mister rytme og kraft. Det er som om det ikke strømmer energi fra menneske til menneske.

\section{Skyldkultur mot skamkultur i Skavlans regi}

Som beskrevet i innledningen, var det et slikt kroppsspråk seerne kunne observere hos Bjarte Baasland, der han satt i studio hos Skavlan den 6. november 2009. På sett og vis ble temaet skam introdusert av programlederen selv, siden han ikke tok sjansen på å la Baasland gjøre sin entré til den tradisjonelle velkomsthilsenen "ta godt imot", ledsaget av applaus fra publikum i salen, slik de øvrige gjestene fikk anledning til. Skavlan må ha ønsket å unngå å vise for et rekordstort seertall det øyeblikket hvor publikum i salen i Stockholm måtte ta stilling til hvor vidt de skulle applaudere den bedrageridømte nordmannen. Kanskje ble Baasland møtt av sjenerende lite applaus fra salen, kanskje var det til og med tilløp til piping. Å vise dette øyeblikket for TV-seerne ville ha vært pinlig i et program som dyrker "den gode samtalen”, og har som målsetting at den skal ende i unison applaus.

Det som skjer i løpet av Skavlans 15 minutter lange intervju med han, er at den bedrageridømte Baasland blir inkludert i “den gode samtalen” ikke bare gjennom intervjuerens empatiske spørsmål, men også gjennom andre gjesters taktfulle bidrag til samtalen. Den gode samtalen passiaren - har allerede fått utfolde seg en god stund. Den startet med at Skavlan introduserte tre kjendiser, sangeren Sissel Kyrkjebø, stand-up komikeren Petter Wahlbeck og radioprateren Hanna Hellquist for å snakke om høflighet. Samtalen dreide seg om “skikk og bruk” eller regler for menneskelig omgang i ulike land, som det å ta hverandre i hendene, kysse på kinnet og gi klemmer. "Skikk og bruk"-diskursen fikk et visuelt uttrykk da den velkledde svenske landslagtreneren i fotball Erik Hamrén gjorde sin entré med et galant bukk til publikum og kyss på hånden til de kvinnelige gjestene. Hamrén viste sin belevenhet både gjennom den historien han fortalte om hvordan han gjorde kur til henne som skulle bli hans kone, og ved å by opp en av de kvinnelige gjestene til dans på scenen. Det er inn i en slik atmosfære av kultivert replikkveksling og demonstrasjon av god etikette gambleren Bjarte Baasland blir invitert for å redegjøre for sin skjebne.

Som allerede nevnt, forteller han om hvordan det hele begynte for han med spill for små beløp på kasinoer under jobbreiser i utlandet, om hvordan spillet som opprinnelig fungerte som avslappende underholdning, gradvis utviklet seg til avhengighet etter at det ble mulig å spille på nettet, og om hvordan han nå bare håper på tilgivelse fra familien. Motivet for å fortelle historien, hevder han til slutt i intervjuet, er å hjelpe andre som også sliter med spilleavhengighet. Men mon ikke Baaslands motiv er dobbelt? Gjennom denne fortellingen skriver han samtidig sin egen biografi, og han gjør det på en måte som gir livet ny mening for han. Han definerer et høyverdig kall for sitt fremtidige liv: han vil redde andre mennesker som ligger under for spillegalskap.

Det er imidlertid vanskelig å oppfatte dette som noe mer enn en situasjonsbestemt ansvarlighet - et påtatt forsøk på å viske ut alle forsmedelser gjennom livet og gi seg selv en identitet 
som foreldrene kanskje vil kunne forsone seg med. I kraft av at han blir godtatt som deltaker i den gode samtalen som Skavlan har dyrket frem, vil talkshowet kunne bidra til nettopp det. Ved at han blir inkludert i den gode samtalen kan skammen vaskes bort, slik at han fremstår som verdig til den applausen Skavlans gjester vanligvis høster. Slik kan han oppnå innpass i berømmelsens - for ikke å si kjendiseriets - ernæringskjede, som Espen Søbye har formulert som en lov: "Når jeg lytter oppmerksomt til din historie, så skal du lytte til min." ${ }^{12}$ Det er samtidig et økonomisk kretsløp, for Skavlans talkshow inngår, som allerede antydet, i markedsføringen av artister og deres kulturprodukter.

Det de 2, 9 millioner norske og svenske seere ikke fikk se, var en hard kritikk som en annen av studiogjestene, Eva Joly, rettet mot Baasland-intervjuet under selve innspillingen av programmet i studio i Stockholm. Ifølge Vårt Land kom hun med denne kommentaren til intervjuet med Baasland:

Pinlig. Jeg lurer på hvorfor dette er i det offentlige rom. Dette er en familietragedie. Det er bare ofrene som kan tilgi, offentlig botsgang tjener ikke til noe. Dette burde ikke ha vcert fjernsynsmat, men bli holdt innenfor hans hus.

Dette utsagnet ble klippet bort, skriver avisen den 9. november, på initiativ fra henne selv. Etter opptak oppdaget Joly at hun hadde ordlagt seg hardere enn hun egentlig kunne stå inne for, og ba om at det ble fjernet. Det dreier seg med andre ord om en selvsensur, som kan virke overraskende. Men mon det ikke er selve programformatet som ved å styre unna polarisert meningsutveksling og ta brodden av ethvert tilløp til kritikk gjør at den kritikken hun formulerer, kan oppleves som upassende i sammenhengen?

Som første gjest i dette talkshowet ble Eva Joly introdusert som "en av verdens fremste eksperter på økonomisk kriminalitet” og intervjuet om sin karriere som korrupsjonsjeger i Frankrike under den såkalte ELF-affæren på 1990-tallet. Vi får høre om det livet hun levde som forhørsdommer i Paris med drapstrusler hengende over seg og med to tungt bevæpnede livvakter boende i leiligheten. Joly lot seg ikke skremme den gang, og hevder at kampen mot korrupsjon fortsatt er viktig fordi vi stadig opplever den, ikke bare i andre europeiske land, men også her hjemme. Hun beskriver en svært utbredt uanstendig pengekultur som innebærer at vi mister sansen for verdiene og "tror at allting bare er penger”. Folk har begynt å tro at det å skaffe seg penger gjør en til et bra menneske, selv om det skjer gjennom korrupsjon. Som fransk politiker og medlem av EU-parlamentet elsker Joly å kunne uttale seg om hva som er rett, og hva som er galt i samfunnet. Slik står Eva Joly gjennom hele dette intervjuet frem som en tydelig talsmann for den skyldkulturen som ligger til grunn for vår moderne rettsstat. I TV-seernes bevissthet gjør hun det i kraft av ikke bare den rollen hun i en årrekke spilte som forhørsdommer i Paris, men også den rollen hun senere har hatt som spesialrådgiver for justis- og utenriksministrene i Norge.

Som kjent oppstår skyld når vi handler i strid med universelle normer og regler. Ofte blir skyld forbundet med protestantismen og den indre fordømmelsen som vår samvittighet represen-

\footnotetext{
${ }^{12}$ I kapitlet "En krympet verden” i boka Ord for ord analyserer Espen Søbye “den gode samtalen” i Skavlans “Først og sist”, og peker på amerikanernes sales tales eller salgsfortellingen som forbildet for den (Søbye, 2005: 223):

"Felles for alle samtalene er ikke bare at deltakerne lytter oppmerksomt til hverandres sales tales, men at de også respekterer disse salgsfortellingene. De er opplyste, liberale mennesker som er tolerante overfor hverandres produkter."
} 
terer. Det er nettopp dette David Riesman gjør når han kontrasterer vår egen tids andrestyrte sosialkarakter med det borgerlige samfunnets indrestyrte karakter. Hos den tradisjonelle borgerlige karakteren fungerte samvittigheten som en form for gyrokontroll og holdt vedkommende på rett kjøl. Gyroskopet var forankret i tydelige felles normer for godt og ondt, og ble internalisert hos de unge gjennom oppdragelse og sosialisering. Der verken oppdragelse eller sosialisering strakk til, måtte rettsstaten gripe inn via domstolene og dømme personer som hadde gjort seg skyldig i krenkelse av samfunnets lover og normer.

Det er en slik skyldkultur Eva Joly har vært en fremtredende representant for gjennom hele sin karriere, og det var den hun målbar i sin sensurerte kritikk av Skavlan-programmet. Her fokuserte hun på nødvendigheten av å skille mellom det som er privat og derfor burde "bli holdt innenfor hans [Baaslands] hus”, og det som "er i det offentlige rom” og derfor kan være “fjernsynsmat”. En rimelig utlegning av hennes resonnement vil være at Baaslands fortelling handler om interne forhold i en familie, om en sønns bønn om foreldrenes tilgivelse, og at en slik fortelling ikke har krav på offentlighetens interesse. Det som kan være av offentlig interesse i en slik sak, har å gjøre med skyld og ansvar, dom og straff - slike forhold som domstolene må ta stilling til. Eva Jolys egen fortelling kretser jo om hva som er rett og galt, hvilke handlinger som ligger innenfor rammen av loven, og hvilke som er lovbrudd og dermed hjemfalne til straff. Det er drøftinger av dette slaget Joly mener bør være “fjernsynsmat”. Her målbærer hun den kritikken som den amerikanske sosiologen Richard Sennett rettet mot utviklingen av den offentlige samtalen i den autoritative studien The Fall of Public Man (1977). Under betegnelsen intimitetstyranniet beskriver Sennett den økende tendensen til å ødelegge det offentlige rommet ved å legge det åpent for private betroelser om personers seksuelle legning, forhold til penger og karaktersvakheter.

Hva kan så grunnen være til at Eva Joly i etterhånd frafaller sin konsekvente "forbrytelse og straff”-diskurs og øver en så påfallende selvkritikk i møtet med Baaslands fortelling om sin egen kriminelle atferd? Mon dette ikke har sammenheng med den vendingen som hun opplever at talkshowet tar mot slutten av intervjuet? Det som begynte som en seriøs dialog om økonomisk kriminalitet og kampen mot den, om risikoen og betydningen av å føre den kampen, og om menneskers manglende evne til å skille mellom godt og ondt, blir etterfulgt av en sketsj-lignende spørreundersøkelse som Skavlans reporter og “løpegutt” Niklas Källner foretar blant mennesker på gata om "hvor korrupte” de er. Niklas tilbyr dem 50 kroner for å svare på hans spørsmål og får flere av dem til å ta imot tilbudet og dermed fremstå som nettopp bestikkelige. Flere av disse situasjonene kaller på latteren, og fenomenet korrupsjon blir i denne videoen omgjort til en karikatur av det samfunnsondet Eva Joly har viet sitt liv til å bekjempe. Vendingen mot parodien og den joviale underholdningen blir foregrepet av Skavlan selv gjennom et avsluttende spørsmål til Joly om hvorvidt moral og verdier i dag er blitt gammeldags.

Med dette retoriske grepet reduserer Skavlan etikk til et spørsmål om hva som er "skikk og bruk” akkurat nå, samtidig som han engasjerer kjente entertainere til en samtale om dette. Eva Joly blir uten videre innlemmet i denne gruppen og dermed lukket inne i den diskursen som føres der. Hun må redegjøre for fransk etikette: hvordan man hilser i hånden og kysser tre ganger på kinnet, og hun lar seg engasjere av den galante svenske landslagstreneren Hamrén til å demonstrere swingdans på scenen. Slik oppstår det en ledig, avslappet atmosfære i studio, en atmosfære som egner seg for små anekdoter fra deltakernes privatsfære: hva Sissel Kyrkjebø kan oppleve når hun er på shoppingtur, hvordan Hamrén klarte å erobre sin tilkommende osv. Talk- 
showet blir en arena for selvfremstilling og i noen grad for egen markedsføring, ettersom flere deltar i dette programmet for å promotere sine nye produkter - det være seg en roman, en film eller ei plate.

For Bjarte Baasland har programmet nettopp en slik dobbeltfunksjon. Han blir tatt inn i en atmosfære hvor han får anledning til å fortelle sin personlige historie, og han gjør det åpenbart med sikte på å fremstå med en ny identitet, en identitet han håper kan appellere til foreldrenes vilje til å tilgi. Vi er vitne til en narsissists bestrebelser på å unnslippe skammen han har pådratt seg og oppnå forsoning med foreldrene. Ved å stå frem på Skavlan og i Rems biografi posisjonerer han seg i det vi har omtalt som kjendiseriets ernæringskjede, der identitet og markedsverdi er tett sammenvevet.

Hvis vi ser bort fra et enkelt spørsmål fra en av de andre deltakerne om hvorvidt Baasland føler dårlig samvittighet overfor foreldrene, er etiske refleksjoner omkring personlig skyld og ansvar helt fraværende i denne samtalen. Baasland blir faktisk møtt med den samme deltagende interesse som de andre intervjuobjektene. Når moral og etikk blir satt til side som her, er det fritt frem for det Eva Joly i begynnelsen av programmet kalte "den uanstendige pengekulturen”. Joly stilte seg kritisk til rådende kultur som går ut på at det å "skaffe seg penger gjør deg til et bra menneske, selv om det er korrupsjon”. Innfor rammen av en slik kultur er det mulig ikke bare å kjøpe seg til heder og ære, men også å rehabilitere en skambefengt identitet gjennom deltakelse i et talkshow som dette eller på andre status- og karrierefremmende arenaer.

For de mange unge som blir tilbudt muligheten til å være deltakere i medienes underholdningsprogram - og slike program blir det stadig flere av - er dette en kjærkommen anledning til å stå frem og iscenesette seg selv, til å presentere et identitetsutkast som man ønsker de andres reaksjon på. Når dertil sosiale medier som Twitter og Facebook er blitt allemannseie og tumleplass for de unge i deres bestrebelser på å finne sin plass i livet, vitner dette om at David Riesmans teori om karakterdannelsen i det postindustrielle samfunn har slått til. Til forskjell fra tidligere generasjoner utvikler dagens ungdom sin identitet under påvirkning av ytre faktorer, først og fremst massemediene.

Imidlertid formes vår tids sosialkarakter - den andrestyrte karakteren i Riesmans terminologi -ikke bare ved at subjektet iscenesetter seg selv i mediene, men også ved at det forholder seg til de fortellingene og bildene som sirkulerer der. Andre personers selvbiografiske fortellinger kan, når de blir formidlet gjennom TV eller andre medier, fungere som råstoff for et ungt publikum som selv strever med sitt identitetsarbeid. Vi vet ingenting om hvordan det rekordstore TVpublikummet reagerte på Bjarte Baaslands forsøk på å gi seg selv en ny identitet ved å fortelle en historie der han la vekt på sine fremtidsvyer. Men når fortolkningsrammen er etablert gjennom den "skikk og bruk"-diskursen historien inngår i, er det relevant å stille spørsmålet om hvor mange det var som kjøpte historien uten å mobilisere noen form for kritisk distanse til den. Dette er et hermeneutisk spørsmål, for tolkningen avhenger av seernes fortolkningshorisont. Blant de svenske seerne kan det neppe ha vært mange som hadde sett presseoppslag om faren, biskop Ernst Baasland, som måtte oppgi sitt embete og forlot landet, og om moren som ble sykehusinnlagt med psykiske problemer. Kanske hadde talkshowets retorikk større gjennomslagskraft blant dem enn blant oss norske seere. Blant oss vil forståelseshorisonten kunne variere både med kulturell kapital og med alder. Mange av oss som er vokst opp med tradisjonell presse og "public service”- kringkasting, vil være tilbøyelige til å vurdere Skavlan-showet med samme kritiske blikk som Eva Joly. Derimot vil yngre seere som både er storforbrukere av sosiale medier og i all 
hovedsak blir informert gjennom underholdningspregede programformater, lett kunne overse de etiske og rettslige dimensjonene og la seg fascinere av den gode samtalen som saken er vevet inn i.

\section{Litteratur}

Andersen, Knut G. (2008): Oslo Byforum - et nettverk for bypolitikk og "globalisering nedenfra”, i: S. Østerud og E. G. Skogseth (red.): A væere på nett. Kommunikasjon, identitets- og kompetanseutvikling med digitale medier. Oslo: Cappelen Akedemisk Forlag, s. 139-158.

Andersen, Knut G., Egil G. Skogseth og Svein Østerud (2008): Fra agora til nettfora. Historiske og politiske forutsetninger for medborger-literacy, i: S. Østerud og E. G. Skogseth (red.): Å vcere på nett. Kommunikasjon, identitets- og kompetanseutvikling med digitale medier. Oslo: Cappelen Akademisk Forlag, s. 117-138.

Augé, Marc (1995): Non-places: introduction to an anthropology of supermodernity. London: Verso.

Baasland, Bjarte og Nils Tore Mosvold (1999): Vikaren, en fremtidig læerer? Ressurshefte for vikarer i grunnskolen. Oslo: Bok og reklameservice.

Bauman, Zygmunt (2001): Flytende modernitet. Oslo: Vidarforlaget.

Beck, Ulrich (2000): Living your own life in a runaway world, i: W. Hutton og A. Giddens (red.): On the edge. Living with global capitalism. London: Jonathan Cape, s. 164-174.

Benedict, Ruth (1946): The Crysanthemum and the Sword. Patterns of Japanese Culture. London: Routledge \& Kegan Paul Ltd.

Crang, Mike (2000): Cultural Geography. London: Routledge.

Drotner, Kirsten (1995): At skabe sig selv: ungdom, cestetik, pædagogik. København:Gyldendal

Drotner, Kirsten og Sonia M. Livingstone (2008): The international handbook of children, media and culture. Los Angeles, California: Sage.

Frønes, Ivar (2009): Skam, skyld og ære i det moderne. I: Trygve Wyller (red.) (2001): Skam. Perspektiver på skam, cere og skamløshet i det moderne. Bergen: Fagbokforlaget, s. 69-80.

Giddens, Anthony (1991): Modernity and Self-Identity. Self and Society in the Late Modern Age, Cambridge: Polity Press.

Kemp, Peter (2005): Verdensborgeren som pæedagogisk ideal. Pcedagogisk filosofi for det 21. århundrede. København: Hans Reitzels Forlag

Kernberg, Otto F. (1975): Borderline conditions and pathological narcissism. New York: Jason Aronson.

Kohut, Heinz (1971): The analysis of the self: a systematic approach to the psychoanalytical treatment of narcissistic personality disorders. New York: International Universities Press.

Kunnskapsløftet. Læreplan for grunnskolen og videregående opplering (LK06). Oslo: UFD. 
Lasch, Christopher (1978): The Culture of Narcissism. American Life in An Age of Diminishing Expectations. New York: W. W. Norton.

Livingstone, Sonia M. (2002): Young People and New Media. Childhood and the changing media environment. London: Sage Publications.

Lüders, Marika, Lin Prøitz og Terje Rasmussen (red.) (2007): Personlige medier. Livet mellom skjermene. Oslo: Gyldendal Akademisk.

Lundby, Knut (red.): Mediatization: concept, changes, consequences. New York: Peter Lang

McLuhan, Marshall (1964): Understanding media: the extensions of man. New York: McGraw-Hill.

Meyrowitz, Joshua (1985): No Sense of Place. The impact of electronic media on social behavior. Oxford: Oxford University Press

Nielsen, Hans-Jørgen (1979): Fodboldenglen: en beretning. København: Tiderne skifter.

Rantanen, Terhi (2005): The Media and Globalization. London: Sage Publications.

Rem, Håvard (2009): Peter Pilný - Historien om Bjarte Baasland. Oslo: Schibsted Forlag.

Rheingold, Howard (1993): The virtual community: homesteading on the electronic frontier. Reading, Mass.: Addison-Wesley.

Riesman, David (1950): The Lonely Crowd. A Study of the changing American character. New Haven: Yale University Press.

Robertson, Roland (1995): Globalization: time-space and homogeneity-heterogeneity, i: M. Featherstone (red.): Global Modernities. London: Sage, s. 25-44.

Sennett, Richard (1977): The Fall of Public Man. New York: Alfred A. Knopf Inc.

Skolefokus nr. 14, 1999. Oslo: Lærerforbundet.

Skårderud, Finn (2001): Tapte ansikter. Introduksjon til en skampsykologi I. Beskrivelser, i: Trygve Wyller (red.) (2001): Skam. Perspektiver på skam, cere og skamløshet i det moderne. Bergen: Fagbokforlaget, s. 37-52.

Søbye, Espen (2005): Ord for ord. Artikler 1986-2004. Oslo: Forlaget Oktober.

Tjønneland, Eivind (2010): Knausgård-koden. Et ideologikritisk essay. Oslo: Spartacus.

Tönnies, F. (1926): Gemeinschaft und Gesellschaft, Grundbegriffe der reinen Soziologie. Berlin: Curtius.

Vettenranta, Soilikki (2010): Mediegrafi. En metode for å forske på og undervise i globalisering. Gyldendal Akademisk

Vårt Land 9. november, 2009.

Ziehe, Thomas (1975): Pubertät und Narzissmus: sind Jugendliche entpolitisiert? Frankfurt a.M.: Europäische Verlagsanstalt. 
Ziehe, Thomas og Herbert Stubenrauch (1983): Ny ungdom og usædvanlige læreprocesser: kulturell friscttelse og subjektivitet. København: Politisk revy.

Wurmser, Léon (1981): The Mask of Shame. Baltimore and London: The Johns Hopkins University Press.

Østerud, Svein (1994): “Golfkrigen” - “kongens død” - “weekend-verten”. Fjernsynets svar på de kulturelle utfordringene i det moderne samfunnet, i: Petter Aasen og Ove Kristian Haugaløkken (red.): Bærekraftig pedagogikk. Identitet og kompetanse i det moderne samfunnet. Oslo: Ad Notam Gyldendal, s. 42-68.

Østerud, Svein (1976): The concept of society in Sophocles: four interpretations. Bergen: Universitetet i Bergen (dr. avhandling).

Østerud, Svein (1982): Den greske tragedie. I: E. Kraggerud (red.), Klassisk og norsk. 12 essays om antikken og den klassiske innflytelse i Norge. Oslo: Gyldendal Norsk Forlag, s. 65-93.

Østerud, Svein og Hans Christian Arnseth (2008): Læring, sosialisering og identitetsutvikling i nettverkssamfunnet. i: Svein Østerud og Egil G. Skogseth (red.): Å være på nett. Kommunikasjon, identitets- og kompetanseutvikling med digitale medier. Oslo: Cappelen Akademisk Forlag, s. 39-59.

Østerud, Svein, Ture Schwebs, Liv Merete Nielsen og Margareth Sandvik (2006): e-Logg - et læringsmiljø for sammensatte tekster. Digital kompetanse 3, s. 214-226. 